\title{
Growth Hormone Bioactivity in Girls with Turner's Syndrome: Correlation with Insulin-like Growth Factor $\mathbf{I}^{1}$
}

\author{
CAROL M. FOSTER, MARIA BORONDY, MARA E. MARKOVS, NANCY J. HOPWOOD, \\ GAD B. KLETTER, AND INESE Z. BEITINS
}

Department of Pediatrics and Communicahle Diseases, Division of Endocrinology: The University of Michigan Medical School, Ann Arhor, Michigan 48109

\begin{abstract}
We have recently developed a new bioassay for growth hormone (GH) in serum, which is based on the ability of GH to suppress glucose use in cultured murine adipocytes. We tested the hypothesis that bioactive GH (B-GH) concentrations would correlate better with the GHdependent peptides, IGF-I, and IGF-binding protein-3 (IGFBP-3) than would GH determined by conventional RIA (RIA-GH). Twenty-five girls with Turner's syndrome were studied. The subjects had ages ranging from 4.8 to $15.9 \mathrm{y}$ and height SD from the mean (SD score) ranging from -0.77 to -5.67 . Blood samples were obtained every 15 or $20 \mathrm{~min}$ for $12 \mathrm{~h}$ overnight. For each girl, an equal aliquot of each overnight sample was pooled for determination of B-GH, RIA-GH, IGF-I, IGFBP-3, LH, FSH, and estradiol. Measurable estradiol concentrations were present in six girls and were sufficient to suppress gonadotropin concentrations in two girls, but they did not alter B-GH, RIA-GH, IGF-I, and IGFBP-3 concentrations compared with the age-matched girls without measurable estradiol concentrations. Hence, data for all girls were combined for subsequent regression analyses. RIA-GH did not correlate significantly with B-GH, IGF-I, or IGFBP-3. BGH exhibited a significant correlation with IGF-I $(r=$ $0.407, p<0.05$ ), and the correlation with IGFBP-3 was better than that for RIA-GH $(r=0.355$ versus 0.064 , BGH and RIA-GH, respectively). None of the B-GH, RIAGH, IGF-I, or IGFBP-3 concentrations had a significant correlation with height SD score or height velocity SD score. These results indicate that B-GH correlates better with the GH-dependent peptides, IGF-I and IGFBP-3, than does RIA-GH, but neither measure of GH is useful in predicting height in girls with Turner's syndrome. (Pediatr Res 35: 218-222, 1994)
\end{abstract}

\section{Abbreviations}

B-GH, bioactive $\mathbf{G H}$

GH, growth hormone

IGFBP-3, IGF-binding protein-3

RIA-GH, growth hormone determined by RIA

SDS, SD score

$\mathrm{CV}$, coefficient of variation

Received May 21, 1993; accepted September 10, 1993.

Correspondence: Carol M. Foster, M.D. D3252 Medical Professional Building Box 0718, 1500 E Medical Center Drive, Ann Arbor, MI 48109-0718.

Supported in part by National Institutes of Health Grant DK-43513 and the Kughn Clinical Research Center (MOl-RR00042).

Presented in part at the 4th Joint Meeting of the Lawson Wilkins Pediatric Endocrine Society-European Society of Paediatric Endocrinology. San Francisco. CA. June 1993.
Although children deficient in GH grow slowly and those with $\mathrm{GH}$ excess grow at an accelerated rate, it has been difficult to relate height or growth velocity to serum $\mathrm{GH}$ concentration as measured by conventional RIA-GH in growing children $(1,2)$. $\mathrm{GH}$ has been shown to exist in a variety of forms in the pituitary gland, and many of these forms are secreted (3). Circulating GH exhibits additional heterogeneity because it is modified in plasma by proteases and binding proteins (3-6). Polyclonal RIA-GH recognize some $\mathrm{GH}$ forms that lack bioactivity, whereas other isoforms, which are highly bioactive, may not be recognized (79). Plasma-binding proteins may modulate $\mathrm{GH}$ bioactivity ( 5 , 6), but they have little effect on GH detection by RIA (10). The significance of $\mathrm{GH}$ isoforms and the interaction of $\mathrm{GH}$ with plasma-binding proteins in the pathophysiologic settings of growth disorders is poorly understood in part because methods for the detection of $\mathrm{GH}$ isoform heterogeneity are difficult to apply to clinical serum samples. Estimation of serum $\mathrm{GH}$ bioactivity has the potential to provide evidence for the presence of differing $\mathrm{GH}$ isoforms or $\mathrm{GH}$ modification by binding proteins in the circulation. Although RIA-GH measurement is useful for detection of $\mathrm{GH}$ deficiency, the determination of $\mathrm{GH}$ bioactivity in serum might enhance our understanding of the role $\mathrm{GH}$ isoforms play in the pathophysiologic settings of growth disorders.

Because of the limitations of available GH bioassays, we recently adapted the physiologically relevant $\mathrm{GH}$-induced suppression of glucose use in murine 3T3-F442A cultured adipocytes for use as an assay to measure $\mathrm{GH}$ bioactivity in human serum samples (11). This assay detects increases of $\mathrm{GH}$ bioactivity after endogenous release or exogenous administration of GHreleasing factor and after pharmacologic stimulation of $\mathrm{GH}$ release by arginine and insulin (11). The purpose of this study was to determine whether $\mathrm{B}-\mathrm{GH}$ concentrations are related to height, the GH-dependent peptides, IGF-I and IGFBP-3, or both $(12,13)$. Our hypothesis was that B-GH concentrations would bear a greater correlation to IGF-I and IGFBP-3 than would GH determined by conventional RIA. Girls with Turner's syndrome were studied because their gonadal dysgenesis results in low estrogen production (14), thereby minimizing the potential impact of changing estradiol concentrations on $\mathrm{GH}$ secretion, bioactivity, and expression of GH-binding protein $(15,16)$. Previous studies estimating $\mathrm{GH}$ bioactivity by radioreceptor assays suggest that $\mathrm{GH}$ bioactivity is similar to that in normally growing girls $(17,18)$. Also, because IGF-I concentrations are similar to those of normal girls, the endogenous $\mathrm{GH}$ in girls with Turner's syndrome is likely to support normal IGF-I production (17). Thus, this population of girls was likely to serve as a good model to determine whether $\mathrm{GH}$ bioactivity in serum determined in a metabolic assay would have a significant correlation with peptides involved in regulation of growth. 


\section{MATERIALS AND METHODS}

Subjects. The ages, heights expressed as SDS (19), body mass indices (kilogram per square meter). and karyotypes of the 25 healthy girls with Turner's syndrome are shown in Table 1. All girls had normal thyroid function study results or were receiving adequate thyroid hormone replacement. None had received prior therapy with $\mathrm{GH}$. One girl, age $9.8 \mathrm{y}$, had received treatment with oxandrolone, and one girl, age $14.3 \mathrm{y}$, had received treatment with conjugated estrogens. All hormonal therapy had been discontinued for at least 6 mo before this study. None of the girls had significant renal or cardiac abnormalities.

Protocols. Studies were performed in the Clinical Research Center of the University of Michigan after informed consent was obtained from a parent. The protocol was approved by the Institutional Review Board of the University of Michigan. Blood was obtained every 15 or $20 \mathrm{~min}$ for $12 \mathrm{~h}$ from either 1800 to $0600 \mathrm{~h}$ or 2000 to $0800 \mathrm{~h}$. Equal aliquots of each sample were pooled and analyzed for RIA-GH, B-GH, IGF-I. IGFBP-3. LH. FSH, and estradiol. Pharmacologic stimulation of GH release by arginine and either clonidine or insulin was performed as a standardized test $(20,21)$ in 23 of the 25 girls.

Hormone assays. All of the patient sample pools were assessed in one immunoassay or bioassay. RIA-GH was determined by a double-antibody RIA as described previously (22) with a standard and a polyclonal anti-GH antibody provided by the National Hormone and Pituitary Program (National Institute of Diabetes and Digestive and Kidney Diseases and the University of Maryland). The assay sensitivity was $0.1 \mu \mathrm{g} / \mathrm{L}$, and the intraassay CV was $4 \%$. LH and FSH were determined in duplicate by Delfia immunoflurometric assay from Wallac (Gaithersburg. MD). The assay sensitivities were 0.3 and $\mathrm{I} \mathrm{IU} / \mathrm{L}$, and the intraassay $\mathrm{CV}$ were 3.0 and $6.0 \%$ for LH and FSH, respectively. Estradiol was determined by RIA with a kit obtained from Diagnostic Products (Carson, CA). The assay sensitivity was $18 \mathrm{pmol} / \mathrm{L}$, and the intraassay CV was $10 \%$. IGF-I and IGFBP-3 were performed with kits provided by Diagnostic Systems Laboratories (Webster, TX). IGF-I was determined by immunoradiometric assay after first undergoing an acid extraction procedure. Reported cross- reactivity with IGF-II, insulin, or proinsulin was negligible, and recovery of IGF-I in serum was $98 \%$. IGFBP-3 was determined by RIA using a polyclonal antibody with specificity for IGFBP. 3. Serum was diluted 1:100 before either IGF-I or IGFBP-3 assays. The assay sensitivities for the standards were $1.3 \mathrm{nmol} / \mathrm{L}$ and $6 \mu \mathrm{g} / \mathrm{L}$, and the intraassay $\mathrm{CV}$ were 13.8 and $7.5^{\circ} \%$ for IGFI and IGFBP-3, respectively.

$\mathrm{GH}$ bioactivity was determined as described previously (11). In brief, standards and serum samples were incubated for $24 \mathrm{~h}$ with 3T3-F442A adipocytes and ${ }^{14} \mathrm{C}$-1)-glucose, $1 \%$ BSA. 1.7 $\mathrm{nmol} / \mathrm{L}$ insulin, $25 \mathrm{nM}$ dexamethasone, and $37 \mathrm{nM}$ estradiol. The medium was discarded, and the lipids were extracted by the method of Dole and Meinertz (23). Radioactivity of the lipids was determined and expressed as counts per minute per dish Data were then normalized as percentage of a control containing incubation medium but no $\mathrm{GH}$ or serum. The assay sensitivity was $0.32 \mu \mathrm{g} / \mathrm{L} \mathrm{GH}$ permitting the detection of $3.2 \mu \mathrm{g} / \mathrm{L} \mathrm{GH}$ in serum, and the intraassay CV was $8.3 \%$.

Statistical analyses. Correlations between age, hormone concentrations, and height were made by regression analysis after logarithmic transformation of the data where appropriate. Comparisons between two groups were made by $t$ test. Comparisons between multiple groups were made by factorial analysis of variance using a Scheffe test. A $p$ value of 0.05 or less was considered significant. Combined data are presented as means \pm SEM.

\section{RESULTS}

Characterization of study population. Girls with Turner's syndrome exhibit karyotype differences (14) that might have an effect on height SDS determination or hormonal concentrations. The patient population was divided into groups having 45.XO; $45, \mathrm{XO} / 46, \mathrm{XX}: 45, \mathrm{XO} / 46, \mathrm{XY}$; iso $\mathrm{X}(\mathrm{q})$, or $\mathrm{r}(\mathrm{X})$ abnormalities. No significant differences were observed in age. height SDS. body mass index, and measures of GH concentration. IGF-I. or IGFBP-3 between any of the groups. Hence, all girls' data were combined in subsequent analyses.

Some girls, because of varying degrees of gonadal dysgenesis.

\begin{tabular}{|c|c|c|c|}
\hline Age $(y)$ & Karyotype & $\begin{array}{l}\text { Height } \\
\text { (SDS) }\end{array}$ & $\begin{array}{l}\text { Body mass index } \\
\left(\mathrm{kg} / \mathrm{m}^{2}\right)\end{array}$ \\
\hline 4.8 & $45 . \mathrm{XO}$ & -3.3 & 16.9 \\
\hline 6.1 & $45 . \mathrm{XO}$ & -0.9 & 15.6 \\
\hline 7.0 & $45 . \mathrm{XO}$ & -2.4 & 15.3 \\
\hline 7.8 & $45, \mathrm{XO} / 46, \mathrm{Xr}(\mathrm{X})$ & -4.3 & 14.4 \\
\hline 7.9 & $45, \mathrm{XO} / 46, \mathrm{XX}$ & -3.4 & 19.4 \\
\hline 8.8 & $45, \mathrm{XO} / 46, \mathrm{Xiso} X(\mathrm{q})$ & -4.1 & 17.4 \\
\hline 9.1 & $45, \mathrm{XO} / 46, \mathrm{XY}$ & -3.4 & 20.8 \\
\hline 9.5 & $45 . \mathrm{XO}$ & -2.7 & 23.8 \\
\hline 9.8 & $45 . \mathrm{XO}$ & -4.0 & 19.8 \\
\hline 10.0 & $45, \mathrm{XO} / 46, \mathrm{Xiso} X(\mathrm{q})$ & -2.0 & 21.5 \\
\hline 11.6 & $45 . \times O$ & -2.1 & 18.2 \\
\hline 11.9 & $45, \mathrm{XO} / 46, \mathrm{XX}$ & -3.7 & 17.2 \\
\hline 12.1 & $45 . \times 0$ & -2.1 & 16.9 \\
\hline 12.4 & 45.XO & -0.8 & 31.0 \\
\hline 12.5 & $45 . \mathrm{XO} / 46, \mathrm{Xr}(\mathrm{X})$ & -4.5 & 16.8 \\
\hline 12.5 & $45, \mathrm{XO} / 46, \mathrm{Xiso} \mathrm{X}(\mathrm{q})$ & -2.7 & 20.2 \\
\hline 12.9 & $46 . X X / 46 . X$ iso $X(q)$ & -2.5 & 29.3 \\
\hline 13.5 & $45, \mathrm{XO} / 46, \mathrm{XY}$ & -3.0 & 17.2 \\
\hline 13.8 & 45.XO/46.Xiso $\mathrm{X}(\mathrm{q})$ & -2.6 & 17.2 \\
\hline 13.8 & $46 . X X / 46, X$ iso $X(q)$ & -4.3 & 16.0 \\
\hline 14.3 & $45, \mathrm{XO} / 46, \mathrm{XY}$ & -4.4 & 24.4 \\
\hline 14.9 & $45, \mathrm{XO} / 47, \mathrm{XXX}$ & -3.0 & 19.2 \\
\hline 14.9 & $45 . \mathrm{XO} / 46 . \mathrm{XY}$ & -3.9 & 18.6 \\
\hline 15.5 & $46, X X / 46, X i s o X(q)$ & -5.7 & 25.3 \\
\hline 15.9 & $45 . \mathrm{XO}$ & -2.6 & 24.4 \\
\hline
\end{tabular}

eristics and hormone data*

\begin{tabular}{|c|c|c|c|c|c|c|}
\hline $\begin{array}{l}\text { Height } \\
\text { (SDS) }\end{array}$ & $\begin{array}{l}\text { Body mass index } \\
\left(\mathrm{kg} / \mathrm{m}^{2}\right)\end{array}$ & $\begin{array}{l}\text { Overnight } G H \\
(\mu \mathrm{g} / \mathrm{L})\end{array}$ & $\begin{array}{l}\text { Stimulated GH } \\
(\mu \mathrm{g} / \mathrm{L})\end{array}$ & $\begin{array}{c}\text { Bioactive } \mathrm{GH} \\
(\mu \mathrm{g} / \mathrm{L})\end{array}$ & $\begin{array}{c}\text { IGF-I } \\
(\mathrm{nmol} / \mathrm{l})\end{array}$ & $\begin{array}{l}\text { IFGBP-3 } \\
(\mathrm{mg} / \mathrm{l})\end{array}$ \\
\hline-3.3 & 16.9 & 0.1 & 14.7 & 5.0 & 1.3 & 2.2 \\
\hline-0.9 & 15.6 & 4.4 & 8.6 & 20.0 & 24.2 & 2.9 \\
\hline-2.4 & 15.3 & 1.6 & 16.1 & 12.0 & 15.7 & 1.9 \\
\hline-4.3 & 14.4 & 0.4 & 19.2 & 8.6 & 18.3 & 2.1 \\
\hline-3.4 & 19.4 & 3.3 & 11.4 & 18.0 & 30.7 & 3.5 \\
\hline-4.1 & 17.4 & 1.2 & 9.7 & ND & 34.0 & 5.0 \\
\hline-3.4 & 20.8 & 2.3 & 3.9 & 23.0 & 6.5 & 2.6 \\
\hline-2.7 & 23.8 & 3.0 & 9.5 & 35.5 & 28.8 & 4.8 \\
\hline-4.0 & 19.8 & 0.1 & 7.2 & 12.5 & 28.8 & 4.2 \\
\hline-2.0 & 21.5 & 1.2 & 5.6 & 8.5 & 35.3 & 2.3 \\
\hline-2.1 & 18.2 & 0.6 & 15.0 & 23.0 & 25.5 & 4.9 \\
\hline-3.7 & 17.2 & 1.8 & 12.1 & 30.0 & 1.7 & 3.4 \\
\hline-2.1 & 16.9 & 1.6 & 7.9 & 12.5 & 19.6 & 3.0 \\
\hline-0.8 & 31.0 & 0.2 & 3.6 & 30.0 & 35.3 & 2.9 \\
\hline-4.5 & 16.8 & 2.3 & 14.6 & 4.5 & 1.3 & 3.0 \\
\hline-2.7 & 20.2 & 2.0 & 12.9 & 3.2 & 3.3 .3 & 5.0 \\
\hline-2.5 & 29.3 & 1.9 & 1.2 & 15.0 & 24.8 & 3.4 \\
\hline-3.0 & 17.2 & 3.5 & 5.9 & 14.0 & 3.4 & 4.7 \\
\hline-2.6 & 17.2 & 0.6 & 2.1 & 50.0 & 56.2 & 5.0 \\
\hline-4.3 & 16.0 & 0.8 & 31.0 & 17.5 & 32.7 & 4.2 \\
\hline-4.4 & 24.4 & 0.5 & 13.2 & 12.0 & 57.5 & 4.7 \\
\hline-3.0 & 19.2 & 4.7 & ND & $24 .()$ & 70.6 & 5.0 \\
\hline-3.9 & 18.6 & 1.1 & 10.1 & 50.0 & 52.3 & 4.3 \\
\hline-5.7 & 25.3 & 0.4 & 13.1 & 38.0 & 32.7 & 4.7 \\
\hline-2.6 & 24.4 & 0.8 & ND & 4.3 & 32.7 & 4.8 \\
\hline
\end{tabular}

*ND, not determined. 
may produce significant amounts of estradiol (14). Because estradiol production could potentially increase $\mathrm{GH}$ concentration (15), the degree to which our study population produced estradiol was assessed by measurement of estradiol, FSH, and LH in overnight serum pools from each subject (Fig. 1). Estradiol was detected in six girls, all of whom were more than $8 \mathrm{y}$ old. Detectable estradiol concentrations were sufficient to reduce serum gonadotropin concentrations into the range expected for normal girls in two of the six girls studied. Comparisons of height SDS and overnight GH, stimulated GH. IGF-I, and IGFBP-3 concentrations were made based on estradiol concentration in the girls who were more than $8 \mathrm{y}$ old. Although girls with detectable estradiol concentrations had greater height SDS $(-2.45 \pm 0.41, n=6)$ than did girls with undetectable estradiol $(-3.53 \pm 0.28, n=14: p<0.05)$, GH, IGF-I, and IGFBP-3 concentrations were not different between groups with detectable compared with undetectable estradiol concentrations (overnight $\mathrm{GH}, 2.0 \pm 0.6$ versus $1.3 \pm 0.3 \mu \mathrm{g} / \mathrm{L}$; peak-stimulated $\mathrm{GH}, 7.1$ \pm 5.2 versus $11.0 \pm 2.0 \mu \mathrm{g} / \mathrm{L}$ : B-GH, $18.5 \pm 4.6$ versus $22.8 \pm$ $4.4 \mu \mathrm{g} / \mathrm{L}$; IGF-I, $33.5 \pm 9.0$ versus $26.4 \pm 3.9 \mu \mathrm{g} / \mathrm{L}$; IGFBP-3. $3.7 \pm 0.5$ versus $3.8 \pm 0.3 \mathrm{mg} / \mathrm{L}$, respectively).

Relationships between B-GH bioactivity or RIA-GH, IGF-I.

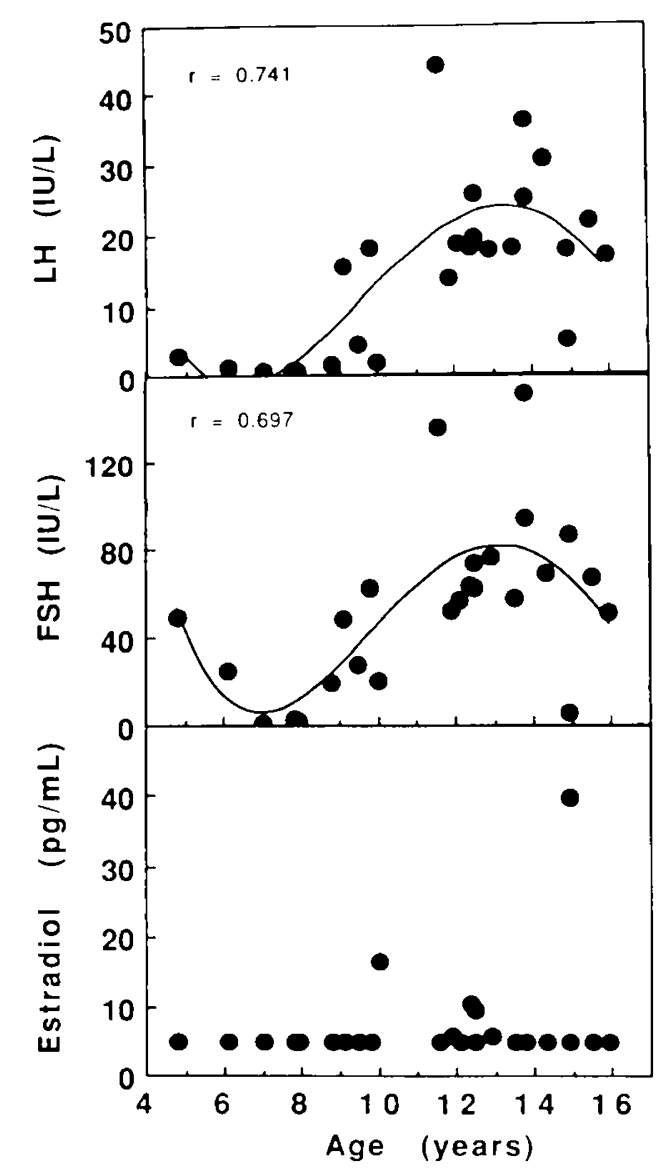

Fig. 1. LH, FSH, and estradiol concentrations in girls with Turner's syndrome. Twenty-five girls with Turner's syndrome had blood obtained every 15 to $20 \mathrm{~min}$ overnight for $12 \mathrm{~h}$. LH. FSH, and estradiol were determined in a pool of the overnight serum samples. and the results were expressed in terms of age in years. $\mathrm{LH}$ and FSH concentrations each demonstrated a 4th order polynomial relationship with age, as the $r$ values indicate. Estradiol was detected in six girls. two of whom had concentrations sufficient to suppress $\mathrm{LH}$ and $\mathrm{FSH}$ into the range expected for normal girls. To convert picograms per miltiliter to picomoles per liter, multiply by 3.67 .
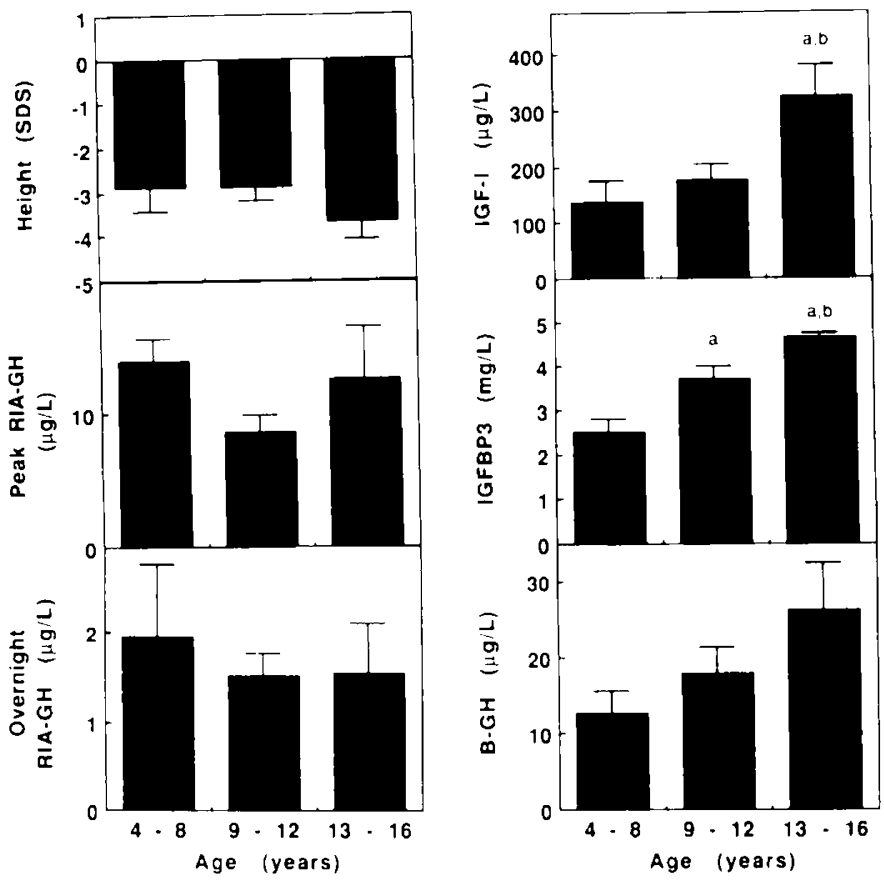

Fig. 2. Height SDS, GH, IGF-I, and IGFBP-3 in girls with Turner's syndrome. Twenty-five girls with Turner's syndrome had measurement of height converted to SDS and determination of RIA-GH. B-GH. IGFI. and IGFBP-3 in a pool of serum made from overnight blood sampling at $15-$ or $20-\mathrm{min}$ intervals. In 23 of the girls, the peak RIA-GH to pharmacologic stimulation of $\mathrm{GH}$ release was also determined. Means and SEM were determined for girls who were 4 to 8,9 to 12 , and 13 to 16 y of age. Bars labeled $a$ indicate values significantly greater than the 4- to 8-y-old group. Bars labeled $h$ indicate values significantly greater than the 9- to 12-y-old group. To convert IGF-I from micrograms per liter to nanomoles per liter. multiply by 0.1307 .

Table 2. Correlation between GH measurements and $I G F-I$ and $I G F B P-3$

\begin{tabular}{ccccc} 
& \multicolumn{2}{c}{ IGF-I } & \multicolumn{2}{c}{ IGFBP-3 } \\
\cline { 2 - 5 } & $\begin{array}{c}\text { Correlation } \\
(r)\end{array}$ & $\begin{array}{c}\text { Significance } \\
(p)\end{array}$ & $\begin{array}{c}\text { Correlation } \\
(r)\end{array}$ & $\begin{array}{c}\text { Significance } \\
(p)\end{array}$ \\
$\begin{array}{c}\text { Overnight } \\
\text { RIA-GH }\end{array}$ & 0.01 & 0.961 & 0.064 & 0.763 \\
$\begin{array}{c}\text { Stimulated } \\
\text { RIA-GH }\end{array}$ & 0.102 & 0.642 & 0.023 & 0.917 \\
Bioactive GH & 0.407 & 0.048 & 0.355 & 0.089 \\
\hline
\end{tabular}

IGFBP-3, and height. RIA-GH concentrations in pooled overnight serum, the peak RIA-GH concentration after pharmacologic stimulation, and B-GH, IGF-I, and IGFBP-3 concentrations for each girl are shown in Table 1. To facilitate comparisons between hormone determinations, we grouped subjects by age to reflect the timing of prepubertal, early to mid-pubertal, and late pubertal development in normal girls. Combined data for ages 4-8 $(n=5), 9-12(n=12)$, and 13-16 $(n=8)$ y are shown in Figure 2. Height SDS and RIA-GH were not significantly different among the groups. No significant correlations were seen between age and height SDS $(r=0.228)$, age and overnight RIA$\mathrm{GH}(r=0.097)$, or age and peak-stimulated RIA-GH $(r=0.047)$. The concentrations of IGF-I and IGFBP-3 increased significantly when compared by age group (Fig. 2) or by regression between age and hormone concentration $(r=0.481, p<0.05$; and $r=$ 0.643, $p<0.005$, for IGF-I and IGFBP-3, respectively). B-GH 
increased with age as well $(r=0.306)$, but the increase did not achieve significance $(p=0.1)$.

B-GH concentrations were positively correlated with IGF-I concentrations, but overnight or peak-stimulated RIA-GH concentrations were not (Table 2). The correlation between B-GH and IGFBP- 3 concentrations were better than that between RIAGH and IGFBP-3 concentrations but did not achieve significance. When measured in serum pools. B-GH and RIA-GH concentrations did not have a significant correlation $(r=0.091)$. Neither B-GH nor overnight RIA-GH concentrations correlated significantly with height SDS ( $r=0.031$ for B-GH and 0.262 for RIA-GH). Height velocity, when expressed as SDS (24), also did not correlate significantly with RIA or B-GH (data not shown).

RIA-GH obtained after pharmacologic stimulation decreased with increasing body mass $(r=0.53, p=0.01)$. The correlation between body mass index and mean RIA-GH was not significant $(r=0.178, p=0.40)$. Also, no significant correlation was observed between body mass index and B-GH $(r=0.138, p=$ $0.52)$.

\section{DISCUSSION}

Because GH release is episodic (25), random measurements of serum GH do not accurately reflect the GH secretory status. Compared with single $\mathrm{GH}$ measurements, the integration of repeated $\mathrm{GH}$ measurements over a 12- to 24-h period has served better as a marker of overall $\mathrm{GH}$ release and, in some cases, has borne some correlation to height SDS, growth rate, or both (1, 2 ). On the basis of our previous study where nocturnal RIA-GH peaks had more B-GH than did troughs (11), it is likely that B$\mathrm{GH}$ varies episodically in serum in a manner similar to RIA$\mathrm{GH}$. To provide an integrated pool of serum on which to estimate B-GH, we combined equal aliquots of each overnight serum sample for an individual patient. The technique of pooling all overnight samples serves to minimize fluctuations of IGF-I and IGFBP-3 as well as reflecting the mean overnight hormone concentrations of GH, LH, and FSH. The LH and FSH determinations made in the pooled sera are similar to those reported previously by Conte et al. (26) on single serum samples in 58 subjects with Turner's syndrome over a span of ages.

Using an integrated approach to measurements of hormone values, we find a significant correlation between B-GH and IGFI in 25 girls with Turner's syndrome. In contrast, RIA-GH measurements in the overnight serum pools and the peak RIAGH response after pharmacologic stimulation do not correlate well with IGF-I. The positive correlation between B-GH and IGF-I is not due to assay cross-reactivity with IGF-I or interference by prolactin (11). Because $\mathrm{GH}$ is known to result in increased IGF-I concentrations in serum (12) and because RIAGH measures both bioactive and bioinactive forms of $\mathrm{GH}(3,8$, 9), B-GH measurements may better reflect the bioactivity of secreted GH forms compared with RIA-GH measurements. The fact that B-GH and RIA-GH do not correlate well in this study also suggests that some of the GH detected by RIA is not biologically active or does not serve to increase IGF-I concentrations in serum. However, because IGF-I concentration in serum is also regulated by nutritional state (27), the possibility exists that IGF-I concentrations reflect a response to $\mathrm{GH}$-induced changes in nutrition or metabolism rather than a direct response to circulating $\mathrm{GH}$. Alternatively, the possibility that $\mathrm{GH}$ bioactivity and IGF-I concentrations both increase in parallel in response to some unknown factor(s) cannot be excluded.

The significant correlation between B-GH and IGF-I, combined with the lack of correlation between B-GH. RIA-GH, or IGF-I and height or growth velocity SDS, suggests that although $\mathrm{GH}$ is required for growth, stature in girls with Turner's syndrome appears to be relatively independent of circulating $\mathrm{GH}$ concentrations. This situation may have occurred. in part. because the height measures made in this study represent one point in time and may be affected by prior hormonal therapies in some of the girls or by parental height. Body weight may also affect apparent $\mathrm{GH}$ secretion and serum concentrations. Although some investigators have demonstrated a decrease in $\mathrm{GH}$ secretion with advancing age (28), others indicate that $\mathrm{GH}$ secretion in these girls is likely to be normal especially if $\mathrm{GH}$ concentrations are normalized to body mass $(29,30)$. Body mass increases with age, and increased body mass has been shown to decrease the amount of secreted GH in girls with Turner's syndrome $(29,30)$. In our study as well, the peak RIA-GH concentrations after pharmacologic stimulation decrease with increasing body mass index.

Zadik et al. (17) have recently suggested that girls with Turner's syndrome lack tissue sensitivity to GH or IGF-I. However, these girls exhibit an increase in growth rate when treated with exogenous GH (31), and their tissue fibroblasts appear to respond normally to IGF-I in vitro (32). Although these data support the hypothesis that girls with Turner's syndrome produce $\mathrm{GH}$ isoforms with subtle differences compared with forms found in normally growing children, indirect bioactivity determinations made previously do not support this notion $(17,18)$. Direct comparisons between bioactivity in girls with Turner's syndrome and normally growing girls using our new GH bioassay may provide additional insights into the presence of $\mathrm{GH}$ isoform differences in future studies.

Our study was designed to determine whether measures of B$\mathrm{GH}$ might correlate better with the GH-dependent peptides. IGFI and IGFBP-3, than do RIA-GH measurements. The fact that $\mathrm{B}-\mathrm{GH}$ determined in this assay changes with age in a manner similar to the GH-dependent peptides. IGF-I and IGFBP-3. indicates that the assay is likely to be useful in furthering our understanding of the role that variation in the bioactivity of serum GH plays in regulating serum concentrations of IGF-I in physiologic and pathophysiologic settings.

Acknowledgment. The authors thank Dr. Vasantha Padmanabhan for her critical review of this manuscript and data.

\section{REFERENCES}

1. Albertson-Wikland K. Rosberg S 1988 Analyses of 24-hour growth hormone profiles in children: relation to growth. J Clin Endocrinol Metab 67:493500

2. Zadik Z. Chalew SA. McCarter Jr RJ. Meistas M. Kowarski AA 1985 The influence of age on the 24-hour integrated concentration of growth hormone in normal individuals. J Clin Endocrinol Metab 60:513-516

3. Lewis UP 1992 Growth hormone: what is it and what does it do? Trends Endocrinol Metab 3:117-121

4. Baumann G. Stolar MW. Amburn K 1985 Molecular forms of circulating growth hormone during spontaneous secretory episodes and in the hasal state. J Clin Endocrinol Metab 60:1216-1220

5. Lim L.. Spencer SA, McKay P. Waters MJ 1990 Regulation of GH bioactivity by a recombinant human $\mathrm{GH}$-binding protein. Endocrinology 127:12871291

6. Fairhall KM. Carmignac DF, Robinson IC 1992 (irowth hormone (GH) binding protein and $\mathrm{GH}$ interactions in vivo in the guinea pig. Endocrinology 131:1963-1969

7. Singh RNP. Seavy BK. Rice VP. Lindsey TT. Lewis UJ 1974 Modified forms of human growth hormone with increased biological activities. Endocrinology $94: 883-891$

8. Brostedt P. Luthman M. Wide L. Werners S, Roos P 1990 ( haracterization of dimeric forms of human pituitary growth hormone by bioassay, radioreceptor assay and radioimmunoassay. Acta Endocrinol (Copenh) 122:241-248

9. Gorden P. Lesniak MA. Hendricks CM. Roth J 1973 "Big" growth hormone components from human plasma: decreased reactivity demonstrated by radioreceptor assay. Science 182:829-831

10. Baumann G 1990 Growth hormone binding proteins and various forms of growth hormone: implications for measurements. Acta Paediatr Suppl $370: 72-80$

11. Foster CM. Borondy M. Padmanabhan V. Schwartz J. Kletter GH, Hopwood NJ, Beitins IZ 1993 Bioactivity of human growth hormone in serum: validation of an in vitro bioassay. Endocrinology 132:2073-2082

12. Furlannetto RW. Underwood LE, Van Wyk JJ. D'Ercole AJ 1977 Estimation of somatomedin-C levels in normals and patients with pituitary disease by radioimmunoassay. J Clin Invest 60:648-657

13. White RM, Nissley SP. Moses AC. Rechler MM. Johnsonbaugh RE 1981 The growth hormone dependence of a somatomedin-binding protein in human serum. J Clin Endocrinol Metab 53:49-57 
14. Lippe B 1987 Turner's syndrome. In: Hintz RL, Rosenfeld RG (eds) Growth Abnormalities. Churchill-Livingstone. New York, pp 187-211

15. Mauras N, Rogol AD, Veldhuis JD 1989 Specific. time-dependent actions of low-dose estradiol administration on the episodic release of growth hormone. and luteinizing hormone in prepubertal girls with Turner's syndrome. J Clin Endocrinol Metab 69:1053-1058

16. Ho KKY, Valiontis E. Waters MJ, Rajkovic IA 1993 Regulation of growth hormone binding protein in man: comparison of gel chromatography and immunoprecipitation methods. J Clin Endocrinol Metab 76:302-308

17. Zadik Z, Landau H. Chen M. Altman Y, Lieberman E 1992 Assessment of growth hormone $(\mathrm{GH})$ axis in Turner's syndrome using 24-hour integrated concentrations of $\mathrm{GH}$. insulin growth factor-1. plasma $\mathrm{GH}$-binding activity, $\mathrm{GH}$ binding to IM9 cells, and $\mathrm{GH}$ response to pharmacological stimulation. J Clin Endocrinol Metab 75:412-416

18. Ilondo MM. Vanderschueren-Lodeweyckx M. De Meyts P. Eggermont E 1990 Serum growth hormone levels measured by immunoassay and radioreceptor assay: a useful diagnostic tool in children with growth disorders? J Clin Endocrinol Metab 70:1445-1451

19. Hamill PVV, Drizd TA. Johnson CL, Reed RB, Roche AF, Moore WM 1979 Physical growth: national center for health statistics percentiles. Am J Clin Nutr 32:607-629

20. Lanes R. Hurtado E 1982 Oral clonidine: an effective growth hormonereleasing agent in prepubertal subjects. J Pediatr 100:710-714

21. Raiti S, Davis WT, Blizzard RM 1967 A comparison of the effects of insulin hypoglycemia and arginine infusion of release of human growth hormone. Lancet 1:321-323

22. Berson SA, Yalow RS, Glick SM, Roth J 1964 Immunoassays of protein and peptide hormones. Metabolism 13:1135-1153
23. Dole V. Meinertz J 1960 Microdetermination of long chain fatty acids in plasma and tissues. J Biol Chem 235:2595-2599

24. Smith DW 1977 Growth and Its Disorders. WB Saunders, Philadelphia

25. Quabbe HJ. Schilling E. Helge H 1966 Pattern of growth hormone secretion during a 24-hour fast in normal adults. J Clin Endocrinol Metab 26:11731177

26. Conte FA. Grumbach MM, Kaplan SL 1975 A diphasic pattern of gonadotropin secretion in patients with the syndrome of gonadal dysgenesis. J Clin Endocrinol Metab 40:670-675

27. Isley WL, Underwood LE, Clemmons DR 1983 Dietary components that regulate serum somatomedin-C concentrations in humans. J Clin Invest $71: 175-182$

28. Ross JL, Long LM. Loriaux DL, Cutler Jr GB 1985 Growth hormone secretory dynamics in Turner's syndrome. J Pediatr 106:202-206

29. Veldhuis JD, Sotos JF, Sherman BM. Genentech Collaborative Group 1991 Decreased metabolic clearance of endogenous growth hormone and specific alterations in the pulsatile mode of growth hormone secretion occur in prepubertal girls with Turner's syndrome. J Clin Endocrinol Metab 73:1073prep 1080

30. Lu PW, Cowell CT, Jimenez M, Simpson JM, Silink M 1991 Effect of obesity on endogenous secretion of $\mathrm{GH}$ in Turner's syndrome. Arch Dis Child 66:1184-1190

31. Rosenfeld RG, Frane J, Attie KM. Brasel JA. Burstein S, Cara JF, Chernausek S. Gotlin RW. Kuntze J, Lippe BM 1992 Six-year results of a randomized prospective trial of human growth hormone and oxandrolone in Turners syndrome. J Pediatr 121:49-55

32. Rosenfeld RG Dollar LA Hintz RL Conover C 1983 Normal somatomedin$\mathrm{C} /$ insulin-like growth factor-I binding and action in cultured human fibroblasts from Turner syndrome. Acta Endocrinol (Copenh) 104:502-509 